\title{
"MEKANISME PENETAPAN WILAYAH PERTAMBANGAN RAKYAT OLEH WALIKOTA SAMARINDA DITINJAU DARI PERATURAN DAERAH NOMOR 12 TAHUN 2013 TENTANG PERTAMBANGAN MINERAL DAN BATU BARA DALAM WILAYAH KOTA SAMARINDA"
}

\author{
Hardiansyah dan Hudali Mukti \\ hardyhardiansyah23@yahoo.com, hudalimukti@uwgm.ac.id \\ Anggota LKBH Dan Dosen Fakultas Hukum Universitas Widya Gama Mahakam Samarinda
}

\begin{abstract}
ABSTRAK
Hasil penelitian menunjukkan bahwa mekanisme penetapan wilayah pertambangan rakyat pada pelaksanaannya dilapangan tidak pernah di implementasikan oleh pemerintah daerah dan terhadap konsultasi Walikota Samarinda dengan Dewan Perwakilan Rakyat Daerah pada pelaksanaannya tidak pernah dilakukan karena terkendala oleh beberapa faktor. Sehingga disarankan pemerintah daerah bisa mengimplementasikan mekanisme penetapan wilayah pertambangan rakyat secara baik sejak dikeluarkannya peraturan daerah tersebut dan pemerintah provinsi sebaiknya mempertimbangkan untuk bisa memberikan izin pertambangan rakyat (IPR) maupun menetapkan wilayah pertambangan rakyat (WPR) di kota samarinda. Penelitian ini bertujuan untuk mengetahui Mekanisme Penetapan Wilayah Pertambangan Rakyat Oleh Walikota Samarinda di tinjau dari Peraturan Daerah Nomor 12 Tahun 2013 Tentang Pertambangan Mineral dan Batubara dalam Wilayah Kota Samarinda dan Bentuk Konsultasi Walikota Samarinda dengan Dewan Perwakilan Rakyat Daerah dalam Penetapan Wilayah Pertambangan Rakyat ditinjau dari Peraturan Daerah No. 12 Tahun 2013 Tentang Pertambangan Mineral dan Batu Bara di Kota Samarinda. Penelitian ini merupakan penelitian hukum Normatif yang bersumber dari bahan hukum sekunder dan bahan hukum primer.
\end{abstract}

Kata Kunci : Mekanisme, Konsultasi, Pertambangan Rakyat

\begin{abstract}
The results showed that the mechanism for the determination of the people in the implementation of the mining area in the field was never implemented by the local government and the Mayor of Samarinda consultation with the Legislative Council on its implementation is never done because it is constrained by several factors. So that local governments can implement the suggested mechanism for the determination of the mining area people as well since the issuance of local regulation and the provincial government should consider in order to give people the mining permit (IPR) and set the artisanal mining area (WPR) in the city of Samarinda. This study aims to determine the mechanism of Zoning Mining People By Mayor of Samarinda in the review of the Regional Regulation No. 12 Year 2013 on Mineral and Coal Mining in the Area Samarinda and Form Consultation Mayor of Samarinda by the regional council in Zoning People Mining in terms of the Regional Regulation No. 12 Year 2013 on Mineral and Coal Mining in Samarinda. This research is a normative law derived from secondary law and primary legal materials.
\end{abstract}

Keywords: Mechanism, Consulting, Mining People 


\section{PENDAHULUAN}

\section{A. Latar Belakang}

Dalam sistem penyelenggaraan pemerintahan daerah, Pemerintah Daerah merupakan salah satu unsur penyelenggaraan urusan pemerintahan di daerah. Pemerintah daerah sebagai salah satu unsur penyelenggaraan urusan pemerintahan di daerah, memerlukan kewenangan dalam penyelenggaraan urusannya. Kewenangan pemerintah daerah merupakan hak dan kekuasaan yang dimiliki oleh pemerintah daerah untuk melakukan penyelenggaraan urusan pemerintahan di daerahnya. Pemerintah Daerah, sesuai dengan amanat Undang-Undang Dasar Negara Republik Indonesia Tahun 1945 berwenang untuk mengatur dan mengurus sendiri urusan pemerintahannya berdasarkan asas otonomi dan tugas pembantuan. Pemerintah daerah kabupaten/kota sebagai salah satu unsur penyelenggaraan urusan pemerintahan di kabupaten/kota, dalam pengelolaan potensi Sumber Daya Alam (SDA) telah diberikan kewenangan, termasuk kewenangan dalam pengelolaan pertambangan rakyat.

Dalam pengelolaan potensi Sumber Daya Alam, walaupun diberikan kewenangan pada daerah, namun diatur dengan ketentuan perundang-undangan maupun peraturan dari pemerintah pusat, seperti dalam hal Pengelolaan pertambangan yang diatur dalam Undang-Undang No. 4 Tahun 2009 tentang Pertambangan Mineral dan Batubara dan Peraturan Pemerintah No. 23 Tahun 2010 Tentang Pelaksanaan Kegiatan Usaha Pertambangan Mineral dan Batubara, kemudian Pemerintah Daerah baik Provinsi maupun Kabupaten/kota diamanatkan untuk membuat Peraturan Daerah sebagai Penjabaran pengaturan di wilayah kerjanya.

Di dalam Undang-Undang Nomor 4 Tahun 2009 tentang Pertambangan Mineral dan Batubara, didalamnya mengatur tentang Wilayah Pertambangan, yang selanjutnya disebut WP, merupakan wilayah yang memiliki potensi mineral dan/atau batubara dan tidak terikat dengan batasan administrasi pemerintah yang merupakan bagian dari tata ruang nasional. Dan didalam ketentuan mengenai Wilayah Pertambangan tersebut didalamnya

${ }^{1}$ Nandang Sudarjat, Teori dan Praktik Pertambangan Indonesia Menurut Hukum, Pustaka mengatur lagi mengenai Wilayah Pertambangan Rakyat, yang selanjutnya disebut WPR, yang merupakan bagian dari WP tempat dilakukan kegiatan usaha pertambangan rakyat.

Terkait penjelasan diatas Nandang Sudrajat dalam buku : Teori Dan Praktik Pertambangan Indonesia Menurut Hukum, menyatakan bahwa :

UU No.4 Tahun 2009 tentang Pertambangan Mineral dan Batubara yang berlaku saat ini, memberikan panduan bahwa pengelolaan dan pengusahaan bahan galian dilakukan secara sistematis sejak penetapan Wilayah Pertambangan yang merupakan bagian dari tata ruang nasional. Proses pelaksanaan penetapan wilayah pertambangan, wilayah usaha pertambangan atau wilayah usaha pertambangan khusus dan wilayah pertambangan rakyat, dilakukan dengan mekanisme yang transparan, akuntabel, dengan melibatkan seluruh elemen, yaitu pemerintah pusat/pemerintah daerah, DPR/DPRD, dan masyarakat. ${ }^{1}$

Dalam pengelolaan pertambangan rakyat, kewenangan pemerintah daerah merupakan hak dan kekuasaan yang dimiliki oleh pemerintah daerah untuk melakukan penataan, pemanfaatan, pemulihan, pengawasan, dan pengendaliaan terhadap kegiatan pertambangan rakyat yang ada di daerah. Berdasarkan Pasal 1 angka 37 UndangUndang Nomor 4 Tahun 2009 tentang Pertambangan Mineral dan Batubara disebutkan bahwa, yang dimaksud dengan Pemerintah Daerah adalah Gubernur, Bupati, atau Walikota, dan perangkat daerah sebagai unsur penyelenggara urusan pemerintahan daerah di bidang pertambangan.

Bupati/Walikota merupakan pejabat yang berwenang dalam Penetapan Wilayah Pertambangan Rakyat (WPR). Bupati/Walikota dalam Penetapan Wilayah Pertambangan Rakyat, berkonsultasi dengan Dewan Perwakilan Rakyat Daerah (DPRD) Kabupaten/Kota untuk memperoleh pertimbangan. Dengan itu, kewenangan untuk melakukan penataan, pemanfaatan, pemulihan, pengawasan, dan pengendaliaan terhadap kegiatan pertambangan rakyat hanya berada pada lingkup urusan daerah kabupaten/kota, dan merupakan kewenangan pemerintah daerah

Yustisia, Yogyakarta, 2010. hal.65. 
kabupaten/kota. Sementara itu, sebagai salah satu kewenangan pemerintah daerah kabupaten/kota dalam pengelolaan pertambangan rakyat dan dalam pengaturan pertambangan rakyat, Penetapan WPR merupakan pengaturan pokok dalam pertambangan rakyat. Berkaitan dengan hal tersebut, Pasal 26 Undang-Undang Nomor 4 Tahun 2009 tentang Pertambangan Mineral dan Batubara menentukan bahwa ketentuan lebih lanjut mengenai kriteria dan mekanisme penetapan WPR diatur dengan peraturah daerah kabupaten/kota.

Berdasarkan ketentuan di atas, menurut hemat penulis dapat dipahami bahwa Pertama, Bupati/Walikota terhadap kewenangan dalam penetapan WPR baru dapat dilaksanankan setelah adanya pengaturan atau ketentuan lebih lanjut tentang kriteria dan mekanisme penetapan WPR. Kedua, dapat dipahami bahwa pemerintah daerah Kabupaten/Kota baru dapat melakukan penataan, pemanfaatan, pemulihan, pengawasan, dan pengendaliaan terhadap kegiatan pertambangan rakyat setelah adanya peraturan daerah yang mengatur tentang pertambangan rakyat sebagai pelaksanaan terhadap ketentuan tersebut. Artinya, dengan adanya ketentuan tersebut, secara khusus kewenangan penetapan WPR oleh Bupati/Walikota dalam pelaksanaannya memerlukan pembuatan Peraturan Daerah Kabupaten/Kota. Begitupula, secara umum pemerintah daerah Kabupaten/Kota dalam artian eksekutif dan legislatif sebagaimana telah ditentukan, dalam melakukan pengelolaan pertambangan rakyat, pelaksanaannya memerlukan pembuatan Peraturan Daerah Kabupaten/Kota sebagai ketentuan lebih lanjut, sekaligus sebagai dasar hukum kewenangannya dalam melakukan pengelolaan pertambangan rakyat di Kabupaten/Kota.

Selain itu, sebagaimana dipahami bahwa hal yang sangat penting dalam pembuatan peraturan perundang-undangan diantaranya adalah menyangkut tentang landasannya. Landasan yang dimaksud disini adalah pijakan, alasan atau latar belakang mengapa perundangan-undangan itu harus dibuat.

2 Bagir Manan dan W. Riawan Tjandra dan Kresno Budi Harsono, Legislatif Drafting Teori dan Teknik Pembuatan Peraturan Daerah, Universitas Atmajaya, Yogyakarta, 2009, hal 28.

${ }^{3}$ Rosyidi Rangga Widjaja dikutip oleh Soimin, Pembentukan Peraturan Negara Di Indonesia,
Menurut Bagir Manan dalam buku legislatif drafting teori dan teknik pembuatan peraturan daerah, ada 4 (empat) landasan yang digunakan dalam pembentukan peraturan perundang-undangan, yaitu : ${ }^{2}$

1. Landasan yuridis, yakni ketentuan hukum yang menjadi dasar kewenangan (bevoegheid, competentie) pembuat peraturan perundang-undangan. Apakah kewenangan pejabat atau badan mempunyai dasar hukum yang ditentukan dalam perundang-undangan atau tidak. Hal ini sangat penting untuk disebutkan dalam perundang-undangan karena seorang pejabat/suatu badan tidak berwenang (onbevogheid) mengeluarkan aturan.

2. Landasan Sosiologis yakni satu peraturan perundang-undangan yang dibuat harus dapat dipahami oleh masyarakat sesuai dengan kenyataan hidup. Ini berarti bahwa hukum yang dibentuk harus sesuai dengan hukum yang hidup (the living law) dalam masyarakat. $^{3}$

3. Landasan Filosofis, yaitu dasar filsafat atau pandangan atau ide yang menjadi dasar sewaktu menuangkan hasrat dan kebijakan (pemerintah) ke dalam suatu rencana atau draft peraturan negara. ${ }^{4}$

4. Landasan Politis, yakni garis kebijakan politik yang menjadi dasar selanjutnya bagi kebijakan dan pengarahan ketatalaksanaan pemerintahan negara.

Berkaitan dengan landasan-landasan tersebut, dengan adanya kewenangan pembuatan Peraturan Daerah dalam pengelolaan pertambangan rakyat, adapun yang menjadi landasan pembuatan Peraturan Daerah oleh pemerintah daerah dalam pengelolaan pertambangan rakyat menurut Salim Hs dalam buku Hukum Pertambangan Mineral dan Batubara yaitu :5

a) landasan filosofis, yaitu dalam rangka memberikan perlindungan hukum terhadap penambang rakyat.

b) landasan sosiologis, yaitu untuk mencegah dan mengatasi serta memberikan perlindungan

2010. hal 30.

4 Budiman NPD, Ilmu Pengantar PerundangUndangan, UII press, Yogyakarta, 2005, hal 33.

5 Salim HS, Hukum Pertambangan Mineral dan Batubara, Sinar Grafika, Jakarta, 2012, hal.104. 
terhadap timbulnya dampak negatif dari kegiatan pertambangan rakyat yang dilakukan oleh masyarakat, yaitu timbulnya kerusakan lingkungan, baik lingkungan sosial maupun fisik.

c) landasan yuridis, yaitu karena adanya perintah Pasal 26, Pasal 72, dan Pasal 143 UndangUndang Nomor 4 Tahun 2009 tentang Pertambangan Mineral dan Batubara.

Di sisi lain, dalam rangka pelaksanaan otonomi daerah, landasan pembentukan Peraturan Daerah tentang pertambangan rakyat adalah bahwa pengelolaan dan pengusahaan pertambangan rakyat merupakan salah satu potensi daerah yang dapat menjadi sumber pendapatan daerah sesuai dengan peraturan perundang-undangan yang berlaku. Berkaitan dengan landasan-landasan tersebut, dengan adanya kewenangan pembuatan Peraturan Daerah dalam pengelolaan pertambangan rakyat, dasar pertimbangan dibentuknya Peraturan Daerah tentang pertambangan rakyat adalah bahwa dalam rangka pelaksanaan otonomi sesuai dengan kewenangan yang dimiliki daerah, perlu melakukan pengaturan, pembinaan, dan pengendalian terhadap pengelolaan dan pengusahaan potensi daerah di bidang pertambangan rakyat untuk menjamin kepastian hukum serta terpeliharanya keseimbangan alam serta kelestarian lingkungan.

Selain itu, sebagai salah satu potensi daerah, pembuatan Peraturan Daerah dalam pengelolaan pertambangan rakyat dapat menjadi sumber pendapatan daerah. Sehingga, pelaksanaannya perlu diusahakan untuk menunjang pemerataan berusaha untuk meningkatkan pembangunan ekonomi lokal atau peningkatan kesejahteraan masyarakat.

Kota Samarinda sebagai salah satu daerah kabupaten/kota yang berada diwilayah Kalimantan Timur, memiliki potensi pertambangan yang cukup besar seperti potensi Pertambangan Mineral dan Batubara. Pemerintah Kota Samarinda dalam hal ini Walikota Samarinda, mempunyai kewenangan dalam hal pengelolaan pertambangan mineral dan batubara sesuai dengan amanat Undangundang No. 4 Tahun 2009 tentang Pertambangan Mineral dan Batubara, dalam Pasal 8 ayat (1) menyatakan bahwa kewenangan pemerintah kabupaten/kota dalam pengelolaan pertambangan mineral dan batubara salah satunya mengenai pembuatan peraturan perundang-undangan daerah. Sehingga, Untuk mengatur pengelolaan pertambangan tersebut, maka Pemerintah Kota Samarinda membuat sebuah kebijakan berupa Peraturan Daerah No. 12 Tahun 2013 Tentang Pertambangan Mineral dan Batubara dalam Wilayah Kota Samarinda, sebagai landasan hukum untuk mengatur pengelolaan pertambangan mineral dan batubara di wilayah Kota Samarinda.

Salah satu kewenangan Walikota Samarinda di dalam Peraturan Daerah No. 12 Tahun 2013 Tentang Pertambangan Mineral dan Batubara dalam Wilayah Kota Samarinda yaitu mengatur tentang Penetapan Wilayah Pertambangan Rakyat (WPR) di daerah Kota Samarinda yang tertuang didalam pasal 9 ayat (1) menyatakan bahwa Wilayah Pertambangan Rakyat (WPR) ditetapkan oleh Walikota, setelah berkonsultasi dengan DPRD. Bahwa berdasarkan hal tersebut diatas, maka Penulis tertarik untuk mengangkat judul Skripsi "Mekanisme Penetapan Wilayah Pertambangan Rakyat Oleh Walikota Samarinda ditinjau dari Peraturan Daerah No. 12 Tahun 2013 Tentang Pertambangan Mineral dan Batu Bara di Kota Samarinda “.

\section{B. Perumusan Masalah}

permasalahan yang diajukan dalam penelitian ini sebagai berikut :

1. Bagaimana Mekanisme Penetapan Wilayah Pertambangan Rakyat oleh Walikota Samarinda ditinjau dari Peraturan Daerah No. 12 Tahun 2013 Tentang Pertambangan Mineral dan Batu Bara di Kota Samarinda ?

2. Apa Bentuk Konsultasi Walikota Samarinda dengan Dewan Perwakilan Rakyat Daerah dalam Penetapan Wilayah Pertambangan Rakyat di Kota Samarinda?

\section{Tujuan dan Manfaat Penelitian}

Adapun yang menjadi tujuan dalam penelitian ini yaitu mengetahui dan menganalisis Mekanisme Penetapan Wilayah Pertambangan Rakyat oleh Walikota Samarinda ditinjau dari Peraturan Daerah No. 12 Tahun 2013 Tentang Pertambangan Mineral dan Batu Bara di Kota Samarinda dan Untuk mengetahui dan menganalisis Bentuk Konsultasi Walikota Samarinda dengan Dewan Perwakilan Rakyat Daerah dalam Penetapan Wilayah Pertambangan Rakyat di Kota Samarinda. 
Adapun penelitian ini diharapkan bermanfaat sebagai bahan bacaan dan sumber pengetahuan maupun sumber informasi bagi masyarakat umum untuk mengetahui Mekanisme Penetapan Wilayah Pertambangan Rakyat oleh Walikota Samarinda ditinjau dari Peraturan Daerah No. 12 Tahun 2013 Tentang Pertambangan Mineral dan Batu Bara di Kota Samarinda. Diharapkan dapat digunakan sebagai salah satu sumber informasi bagi masyarakat untuk mengetahui Bentuk Konsultasi Walikota Samarinda dengan Dewan Perwakilan Rakyat Daerah dalam Penetapan Wilayah Pertambangan Rakyat ditinjau dari Peraturan Daerah No. 12 Tahun 2013 Tentang Pertambangan Mineral dan Batu Bara di Wilayah Kota Samarinda.

\section{METODE PENELITIAN}

\section{Jenis Penelitian}

Berdasarkan permasalahan yang diteliti oleh penulis, maka dalam penelitian ini, penulis menggunakan metode penelitian hukum Normatif (Yuridis Normatif). Penelitian Hukum Normatif, yaitu penelitian yang mempergunakan bahan-bahan kepustakaan sebagai sumber data penelitiannya. ${ }^{6}$ Untuk menunjang dan melengkapi data, maka dilakukan penelitian lapangan yaitu penelitian yang dilaksanakan dengan cara terjun langsung kelapangan untuk memperoleh data sekunder. ${ }^{7}$

\section{Bahan Hukum}

A. Bahan Hukum Primer, yaitu bahan hukum yang bersifat mengikat yang terdiri dari :

1) Undang-Undang Dasar 1945

2) Undang-Undang Nomor 4 Tahun 2009 Tentang Pertambangan Mineral dan Batu Bara.

3) Undang-Undang Nomor 23 Tahun 2014 tentang Pemerintahan Daerah Jo Undang-Undang Nomor 9 Tahun 2015 tentang Perubahan kedua atas Undang-Undang Nomor 23 Tahun 2014.

4) Peraturan Pemerintah Nomor 23 Tahun 2010 Tentang Pelaksanaan Kegiatan Usaha Pertambangan Mineral dan Batubara.

5) Peraturan Daerah Nomor 12 Tahun

6 Amiruddin dan Zainal Asikin, Pengantar Metode Penelitian Hukum, RajaGrafindo Persada, jakarta, 2004, hal. 166
2013 Tentang Pertambangan Mineral dan Batubara dalam Wilayah Kota Samarinda.

B. Bahan Hukum Sekunder, yaitu bahan hukum yang memberikan petunjuk dan kerjasama terhadap bahan hukum primer, yaitu terdiri dari buku-buku liteatur, makalah, artikel, hasil penelitian dari karya ilmiah lainnya yang berhubungan dengan penelitian ini.

C. Bahan Hukum Tersier, yaitu bahan hukum yang memberikan petunjuk maupun penjelasan terhadap bahan hukum primer dan bahan hukum sekunder

\section{Metode dan Teknik Pengumpulan Data}

Dalam Penyusunan Karya Ilmiah ini Peneliti melakukan metode dan pengumpulan data dengan cara yakni sebagai berikut :

A. Studi Kepustakaan dan Studi Dokumen yaitu dengan cara mempelajari, mengkaji dan mengolah bahan-bahan hukum, baik bahan hukum primer, bahan hukum sekunder maupun bahan hukum tersier.

B. Wawancara (interview)

Penggunaan teknik wawancara dalam penelitian ini didasari pertimbangan, melalui wawancara dengan pemerintah Kota Samarinda selaku pihak yang melakukan penetapan wilayah pertambangan rakyat di kota samarinda dan Dinas Pertambangan dan Energi Kota Samarinda. Tujuan penggunaan panduan wawancara (Interview guide) agar fokus wawancara tidak keluar dari konteks penelitian. Secara teoritis wawancara yang menggunakan panduan wawancara tersebut disebut wawancara campuran.

\section{Analisis Data}

Data yang telah dikumpulkan dari penelitian kepustakaan maupun dari penelitian lapangan selanjutnya dianalisis secara kualitatif, yaitu metode analisis data dengan cara mengelompokkan dan menyeleksi data yang diperoleh dari penelitian menurut kualitas dan kebenarannya, kemudian dihubungkan dengan teori-teori dari studi kepustakaan sehingga diperoleh jawaban atas permasalahan dalam penelitian ini. Dalam analisis data ini

7 Soerjono Soekanto dan Sri Mamudji, Penelitian Hukum Normatif Suatu Tinjauan Singkat, RajaGrafindo Persada, jakarta, 2003, hal. 13 
digunakan cara berfikir induktif, yaitu menyimpulkan hasil penelitian dari hal yang bersifat khusus untuk kemudian diambil kesimpulan yang bersifat umum.

\section{PEMBAHASAN}

\section{A. Mekanisme Penetapan Wilayah Pertambangan Rakyat Oleh Walikota Samarinda Ditinjau Dari Peraturan Daerah Nomor 12 Tahun 2013 Tentang Pertambangan Mineral dan Batu Bara Dalam Wilayah Kota Samarinda.}

Sebelum suatu wilayah ditetapkan sebagai wilayah pertambangan rakyat terdapat beberapa kriteria untuk menetapkan wilayah pertambangan rakyat sebagaimana yang termuat didalam ketentuan mengenai wilayah petambangan didalam Peraturan Daerah Nomor 12 Tahun 2013 tentang pertambangan mineral dan batubara dalam wilayah kota samarinda. Kriteria untuk menetapkan wilayah pertambangan rakyat terkandung didalam pasal 10 yakni sebagai berikut :

1) Mempunyai cadangan mineral sekunder yang terdapat disungai dan/atau diantara tepi dan tepi sungai;

2) Mempunyai cadangan primer logam atau batubara dengan kedalaman maksimal 25 (dua puluh lima) meter;

3) Endapan teras, dataran banjir, dan endapan sungai purba;

4) Luas maksimal wilayah pertambangan rakyat adalah 25 (dua puluh lima) hektar;

5) Menyebutkan jenis komoditas yang akan ditambang; dan/atau

6) Merupakan wilayah atau tempat kegiatan tambang rakyat yang sudah dikerjakan sekurang-kurangnya 15 (lima belas) tahun.

Dari kriteria WPR di atas jika dikaji, pertama, untuk huruf (d) apabila WPR maksimal wilayahnya 25 hektar, dan tiap orang mendapat wilayah 1 hektar, maka untuk 1 WPR hanya terdapat 25 orang penambang, atau kalau kelompok masyarakat, dan tiap kelompok mendapat 5 hektar, maka akan ada maksimal 5 kelompok penambang, atau kalau koperasi, dan tiap koperasi mendapat 10 hektar, maka akan ada maksimal 2 sampai 3 koperasi penambang. Dari sini dapat diperkirakan bahwa penambang yang dapat memiliki IPR di wilayah WPR sangat terbatas, artinya serapan tenaga kerja dari pertambangan rakyat tidak banyak, apalagi sumber daya ini adalah sumber daya yang tidak dapat diperbaharui, sehingga dapat disimpulkan bahwa kegiatan ini hanya bersifat temporer atau tidak dapat diharapkan berlangsung terus menerus.

Kemudian untuk kriteria huruf (f) yaitu bahwa kegiatan pertambangan tersebut sudah dikerjakan sekurang-kurangnya minimal 15 tahun, artinya di sini untuk menentukan daerah suatu wilayah menjadi WPR di Kota Samarinda sangat sulit, karena ketentuan batas minimal aktivitas pertembangan tersebut cukup lama. Yang tidak kalah pentingnya adalah bahwa norma tentang kriteria penentuan WPR bersifat 'komulatif', ini berarti bahwa untuk menentukan suatu wilayah menjadi WPR harus memenuhi syarat-syarat tersebut secara keseluruhan.

Dalam hal menetapkan suatu wilayah menjadi wilayah pertambangan rakyat, pemerintah kota samarinda dalam hal ini eksekutif, legislatif dan unsur lainnya bersamasama saling berkoordinasi untuk menetapkan suatu wilayah pertambangan rakyat. Sebagai pemerintah kota samarinda, walikota samarinda dalam hal menetapkan suatu wilayah menjadi wilayah pertambangan rakyat mempunyai mekanisme penetapan wilayah pertambangan rakyat yakni sebagai berikut :

1. Walikota melakukan Penyusunan Rencana Wilayah Pertambangan Rakyat (WPR)

Pada Proses Penyusunan Rencana Wilayah Pertambangan Rakyat, terhadap masyarakat yang memiliki hak atas tanah dalam WPR berhak mendapatkan koordinasi dari Pemerintah Daerah. Koordinasi yang dilakukan oleh Pemerintah Daerah yakni dalam rangka mencapai kesepakatan dengan Pemilik Hak Atas Tanah untuk ditetapkan sebagai WPR.

$$
\text { Walikota berkewajiban untuk }
$$
mengumumkan mengenai rencana WPR kepada masyarakat secara terbuka. Pengumuman rencana WPR dilakukan di Kantor Desa/Kelurahan/ Instansi terkait, dilengkapi dengan peta situasi yang menggambarkan lokasi, luas dan batas situasi serta daftar koordinat dan dilengkapi daftar pemegang hak atas tanah yang berada dalam WPR. Perencanaan WPR disusun melalui Inventarisasi potensi pertambangan rakyat. Inventarisasi potensi pertambangan rakyat dilakukan untuk mengumpulkan data dan 
informasi mengenai potensi pertambangan yang dapat digunakan sebagai dasar penyusunan rencana penetapan WPR. Potensi pertambangan rakyat dikelompokkan atas pertambangan mineral dan pertambangan batubara. Pertambangan mineral dan batubara dikelompokkan ke dalam 4 (Empat) golongan komoditas tambang:

a. mineral logam;

b. mineral bukan logam;

c. batuan; dan

d. batubara;

Inventarisasi potensi pertambangan rakyat dilakukan melalui kegiatan penyelidikan dan penelitian pertambangan. Penyusunan Rencana WPR digunakan sebagai dasar untuk penetapan WPR.

2. Walikota melakukan penyelidikan dan penelitian dalam rangka mempersiapkan Wilayah Pertambangan Rakyat (WPR)

Penyelidikan dan penelitian dilakukan untuk memperoleh data dan informasi yakni sebagai berikut :

a. formasi batuan pembawa mineral dan/atau batubara;

b. data geologi hasil evaluasi dari kegiatan pertambangan yang sedang berlangsung, telah berakhir, dan/atau telah dikembalikan walikota;

c. data perizinan hasil inventarisasi terhadap perizinan yang masih berlaku, yang sudah berakhir, dan/atau yang sudah dikembalikan kepada walikota sesuai dengan kewenangannya.

Penyelidikan dan penelitian pertambangan rakyat sebagaimana dimaksud diatas dilaksanakan secara terkoordinasi oleh Walikota sesuai dengan kewenangannya. Dalam melakukan kegiatan penyelidikan dan penelitian pertambangan rakyat, Walikota memberikan penugasan kepada Dinas Pertambangan dan Energi Kota Samarinda. Penugasan yang diberikan kepada Dinas Pertambangan dan Energi Kota Samarinda dilakukan untuk menunjang penyiapan WPR. Dinas Pertambangan dan Energi Kota Samarinda wajib:

a. menyimpan, mengamankan, dan merahasiakan data dan informasi potensi pertambangan rakyat hasil penyelidikan dan penelitian sesuai dengan ketentuan peraturan perundangan-undangan; dan b. menyerahkan seluruh data dan informasi potensi pertambangan yang diperolehnya kepada Walikota yang memberi penugasan.

Walikota sesuai dengan kewenangannya menetapkan wilayah penugasan penyelidikan dan penelitian pertambangan rakyat yang akan dilaksanakan oleh Dinas Pertambangan dan Energi Kota Samarinda dan dituangkan dalam peta. Walikota dalam menetapkan wilayah penugasan sebagaimana dimaksud diatas berkoordinasi dengan Pemerintah Provinsi. Walikota dapat mengusulkan suatu wilayah penugasan untuk dilakukan penyelidikan dan penelitian pertambangan rakyat kepada Pemerintah Provinsi. Peta yang dimaksud sebagai dasar dalam memberikan penugasan penyelidikan dan penelitian pertambangan kepada Dinas Pertambangan dan Energi Kota Samarinda. Data dan informasi hasil penyelidikan dan penelitian pertambangan rakyat yang dilakukan oleh Walikota wajib diolah menjadi peta potensi mineral dan/atau batubara. Peta potensi mineral dan/atau batubara paling sedikit memuat informasi mengenai formasi batuan pembawa mineral dan/atau pembawa batubara. Walikota wajib menyampaikan peta potensi mineral dan/atau batubara kepada Pemerintah Provinsi. Berdasarkan peta potensi mineral dan/atau batubara, Walikota melakukan evaluasi. Hasil evaluasi digunakan oleh Walikota sebagai bahan penyusunan rencana WPR..

3. Hasil Penyelidikan dan Penelitian selanjutnya dikoordinasikan dengan Pemerintah Provinsi dan dilaporkan secara tertulis kepada DPRD kabupaten/kota.

Koordinasi dengan Pemerintah Provinsi dilakukan untuk mendapatkan pertimbangan berkaitan dengan data dan informasi yang dimiliki oleh Pemerintah Provinsi. Hasil Penyelidikan dan Penelitian yang dilaporkan secara tertulis kepada DPRD kabupaten/kota dilakukan untuk memperoleh pertimbangan.

4. Walikota melakukan Penetapan Wilayah Pertambangan Rakyat (WPR)

A. Dalam rangka penetapan WPR oleh Walikota harus meliputi sekurangkurangnya :

1) Penetapan WPR dilakukan setelah berkoordinasi dengan pemerintah provinsi dan berkonsultasi dengan 
Dewan Perwakilan Rakyat Daerah kabupaten/kota;

2) Sebelum melakukan koordinasi dengan pemerintah provinsi dan konsultasi dengan Dewan Perwakilan Rakyat Daerah kabupaten/kota, wajib memastikan yakni :

a. Lokasi WPR :

1. Masuk dalam Kawasan Peruntukan Pertambangan sebagaimana tercantum dalam rencana tata ruang wilayah kabupaten/kota yang ditetapkan dalam Peraturan Daerah;

2. Telah mendapatkan persetujuan dari pemegang hak atas tanah sesuai dengan ketentuan peraturan perundang-undangan;

3. Telah menggunakan sistem koordinat pemetaan dengan Datum Geodesi Nasional yang mempunyai parameter sarna dengan parameter Ellipsoid World Geodetic System;

4. Telah memenuhi kriteria penetapan WPR sesuai dengan ketentuan peraturan perundang-undangan; dan

5. Telah dilaksanakan pengumuman rencana penetapan WPR kepada masyarakat seeara terbuka paling sedikit pada kantor kelurahan/desa di lokasi WPR sesuai dengan ketentuan peraturan perundangundangan.

b. Luasan WPR;

Luas maksimal wilayah pertambangan rakyat adalah 25 (dua puluh lima) hektar.

c. Jenis komoditas yang ditambang;

Pertambangan Rakyat dikelompokkan ke dalam 4 (Empat) golongan komoditas tambang :

1. mineral logam;

2. mineral bukan logam;

3. batuan; dan

4. batubara;

\section{d. Gambar peta lokasi WPR.}

B. Wilayah atau tempat kegiatan tambang rakyat yang sudah dikerjakan tetapi belum ditetapkan sebagai WPR diprioritaskan untuk ditetapkan sebagai
WPR.

C. WPR yang telah ditetapkan disampaikan secara tertulis oleh Walikota kepada Menteri dan Gubernur.

D. Penetapan Wilayah Pertambangan Rakyat ditetapkan dengan Keputusan Walikota.

Menurut Hemat Penulis, dari keseluruhan rangkaian mekanisme penetapan wilayah pertambangan rakyat oleh walikota samarinda yang dijelaskan diatas, pemerintah kota samarinda maupun aparatur yang menjalankannya belum mampu untuk mengimplementasikannya di lapangan. Terbukti bahwa sampai saat ini pemerintah kota samarinda tidak pernah mengeluarkan izin pertambangan rakyat (IPR) maupun menetapkan suatu wilayah pertambangan rakyat (WPR) di Kota Samarinda. Sehingga, pertambangan rakyat yang dikerjakan oleh masyarakat setempat di kota samarinda itu dilakukan secara ilegal. Padahal didalam Peraturan Daerah Nomor 12 Tahun 2013 Tentang Pertambangan Mineral dan Batubara dalam Wilayah Kota Samarinda sudah jelas ada ketentuan yang mengatur tentang Izin Pertambangan Rakyat dan penetepan Wilayah Pertambangan Rakyat (WPR) di Kota Samarinda. Akan tetapi, pada kenyataannya tidak pernah di implementasikan secara baik oleh pemerintah kota samarinda.

Yang menjadi alasan kenapa pemerintah kota samarinda tidak pernah mengeluarkan Izin Pertambangan Rakyat maupun menetapkan Wilayah Pertambangan Rakyat di Kota Samarinda yakni dapat dilihat dari beberapa contoh Pertambangan Rakyat yang pernah ada di Kota Samarinda yang tidak memiliki Izin pertambangan rakyat (IPR) dan tidak ditetapkan wilayahnya sebagai Wilayah Pertambangan Rakyat oleh pemerintah kota samarinda yakni sebagai berikut :

a) Penambangan Pasir di Sungai Mahakam

Penambangan Pasir yang dilakukan sejak dulu oleh masyarakat setempat kota samarinda di sungai mahakam sudah berlangsung cukup lama. Akan tetapi, sejak saat itu hingga dikeluarkannya Perda Nomor 12 Tahun 2013 Tentang Pertambangan Mineral dan Batu Bara dalam wilayah kota samarinda, pertambangan pasir tersebut pun tidak pernah memiliki izin pertambangan rakyat (IPR) maupun memiliki wilayah pertambangan rakyat yang di legalkan oleh pemerintah kota samarinda. Yang menjadi 
alasan kenapa pemerintah kota samarinda tidak mengeluarkan Izin Pertambangan Rakyat (IPR) dan tidak menetapkan suatu wilayah pertambangan rakyat kepada masyarakat yang melakukan penambangan pasir di sungai mahakam yakni karena :

1) Kesulitan dalam Pembagian Wilayah Izinnya

Pembagian wilayah izin penambangan pasir disungai mahakam dapat dikatakan sangat sulit karena yang perlu diketahui bahwa sungai mahakam dikota samarinda yang mempunyai material pasir cukup banyak dan wilayahnya yang luas akan membuat pemerintah kota samarinda sangat kesulitan untuk menentukan wilayah bagi masyarakat penambang pasir yang satu dengan penambang pasir lainnya. Apalagi material pasir disungai mahakam tidak serta merta selalu ada dan selalu berpindah-pindah, misalnya saja apabila penambang pasir A sudah ditetapkan suatu wilayah penambangannya dan suatu ketika diwilayahnya tersebut telah habis material pasirnya maka secara otomatis penambang pasir A tersebut pasti akan berpindah kewilayah yang lain, wilayah dimana yang diperkirakan masih memiliki material pasir. Hal inilah yang akan menjadi salah satu pertimbangan oleh pemerintah kota samarinda tidak memberikan izin pertambangan rakyat, terlebih lagi disungai mahakam terdapat beberapa wilayah-wilayah tertentu yang dilarang untuk dilakukan penambangan pasir seperti wilayah sekitar jembatan. Sehingga penambangan pasir yang dilakukan disungai mahakam kesemuanya merupakan pertambangan ilegal.

\section{2). Keterbatasan Sumber Daya Manusia yang mengawasinya}

Dengan banyaknya masyarakat yang melakukan penambangan pasir disungai mahakam membuat pemerintah kota samarinda akan kesulitan untuk mengontrol para penambang pasir di sungai mahakam karena keterbatasan sumber daya manusia yang mengawasinya, apalagi para penambang pasir di sungai mahakam kebanyakan dilakukan pada malam hari. Oleh sebab itu, sejak dulu hingga dikeluarkannya Perda Nomor 12 Tahun 2013 Tentang Pertambangan Mineral dan Batu Bara dalam wilayah kota samarinda, pemerintah kota samarinda tidak pernah melegalkannya.

b) Penambangan Batu Cermin dan Batu Besaung di Sempaja Utara
Penambangan Batu Cermin dan Batu Besaung di Sempaja Utara yang dilakukan oleh masyarakat setempat kota samarinda juga telah berlangsung cukup lama, akan tetapi penambangan batu cermin dan batu besaung tersebut pun tidak memiliki izin atau dianggap ilegal oleh pemerintah kota samarinda. Yang menjadi alasan kenapa pemerintah kota samarinda tidak mengeluarkan Izin Pertambangan Rakyat (IPR) dan Menetapkan Wilayah Pertambangan Rakyat (WPR) kepada para penambang batuan tersebut yakni karena pemerintah kota samarinda beranggapan bahwa penambangan batuan tersebut akan memberikan dampak negatif pada lingkungan sekitar. Karena tidak didukung dengan kajian analisis dampak lingkungan (AMDAL).

Perlu diketahui bahwa pemerintah kota samarinda untuk melegalkan tambang rakyat di kota samarinda bukan seperti membalik telapak tangan atau dapat dilakukan tanpa mempertimbangkan aspek aturanya. Penyebab penambangan ilegal di kota samarinda yakni karena pertambangan yang dilakukan oleh masyarakat kota samarinda kebanyakan dilakukan tanpa izin dan dilakukan bukan di wilayah yang memang diperuntukkan untuk kegiatan pertambangan, perlatan yang digunakan untuk melakukan kegiatan penambangan pun tidak memenuhi unsur kesehatan, keamanan dan keselamatan kerja, serta aktivitasnya juga mengenyampingkan aspek-aspek lingkungan karena tidak memiliki Amdal. Sehingga, karena hal-hal tersebutlah pemerintah kota samarinda tidak pernah melegalkan pertambangan rakyat di kota samarinda.

\section{B. Bentuk Konsultasi Walikota Samarinda dengan Dewan Perwakilan Rakyat Daerah dalam Penetapan Wilayah Pertambangan Rakyat ditinjau dari Peraturan Daerah No. 12 Tahun 2013 Tentang Pertambangan Mineral dan Batu Bara di Kota Samarinda}

Proses konsultasi yang dilakukan oleh Walikota Samarinda dengan Dewan Perwakilan Rakyat Daerah (DPRD) Kota Samarinda mengenai Penetapan Wilayah Pertambangan Rakyat di Kota Samarinda yakni dilakukan dalam bentuk tertulis, adapun Isi materi di dalam konsultasi yang dilakukan dalam bentuk tertulis oleh Walikota Samarinda dengan Dewan Perwakilan Rakyat Daerah (DPRD) 
Kota Samarinda mengenai Penetapan Wilayah Pertambangan Rakyat di Kota Samarinda yakni Membahas :

1. Membahas Tentang Kriteria Penetapan Wilayah Pertambangan Rakyat nya Didalam pembahasan terkait Kriteria Penetapan Wilayah Pertambangan Rakyat (WPR) yakni dilakukan untuk mengetahui apakah suatu wilayah yang ingin ditetapkan sebagai wilayah pertambangan rakyat tersebut sudah memenuhi kriteria untuk di tetapkan sebagai Wilayah Pertambangan Rakyat atau belum memenuhi kriteria untuk ditetapkan.

2. Membahas Hasil Penyusunan Rencana Wilayah Pertambangan Rakyat yang telah dilakukan oleh Walikota Samarinda

Didalam pembahasan terkait Penyusunan Rencana Wilayah Pertambangan Rakyat (WPR) yang telah dilakukan oleh Walikota Samarinda yakni dilakukan untuk mengetahui daftar pemegang hak atas tanah yang berada dalam Wilayah Pertambangan Rakyat (WPR). Tujuannya yakni untuk mengetahui apakah wilayah tersebut telah mendapatkan persetujuan dari pemegang hak atas tanah dan apakah sudah dilakukan pembebasan lahan oleh pemerintah kota samarinda dari pemegang hak atas tanah tersebut. Sehingga, wilayah yang ingin ditetapkan tersebut nantinya tidak menimbulkan sengketa.

3. Membahas Hasil penyelidikan dan penelitian yang telah didapatkan oleh Walikota Samarinda

Dari hasil penyelidikan dan penelitian yang telah didapatkan oleh Walikota Samarinda selanjutnya data dan informasi yang telah diperoleh tersebut di lampirkan didalam konsultasi yang dilakukan secara tertulis yang mana tujuannya untuk mengetahui tentang :

a. Lokasi Wilayah Pertambangan Rakyat nya

b. Luasan Wilayah Pertambangan Rakyat nya

c. Jenis komoditas yang ditambang

d. Gambar peta lokasi Wilayah Pertambangan Rakyat nya.

Selanjutnya dari hasil pembahasan dalam konsultasi tersebut, DPRD Kota Samarinda membuat suatu pertimbangan yang mana hasil pertimbangan yang dibuat oleh DPRD Kota Samarinda tersebut menyatakan menyetujui atau tidak penetapan wilayah yang akan dilakukan oleh Walikota Samarinda.
Dari Fakta yang penulis dapatkan dilapangan, konsultasi yang dilakukan oleh Walikota Samarinda dengan Dewan Perwakilan Rakyat Daerah dalam menetapankan wilayah pertambangan rakyat di kota samarinda pada kenyataannya tidak pernah di lakukan oleh pemerintah kota samarinda karena dipengaruhi oleh beberapa faktor yakni sebagai berikut :

1. Pertambangan Rakyat di Kota Samarinda kebanyakan tidak memenuhi Kriteria untuk ditetapkan sebagai Wilayah Pertambangan Rakyat (WPR).

Di Kota Samarinda hampir semua kegiatan pertambangan rakyat yang ada tidak memenuhi kriteria untuk ditetapkan sebagai wilayah pertambangan rakyat (WPR). Salah satu kriteria agar bisa ditetapkan wilayahnya sebagai wilayah pertambangan rakyat yakni sudah dikerjakan sekurang-kurangnya minimal 15 tahun, artinya di sini untuk menentukan daerah suatu wilayah menjadi WPR di Kota Samarinda sangat sulit, karena ketentuan batas minimal aktivitas pertembangan tersebut cukup lama. Terlebih lagi untuk menentukan suatu wilayah menjadi WPR harus memenuhi syaratsyarat tersebut secara keseluruhan.

2. Pemerintah Kota Samarinda tidak pernah mengeluarkan Izin Pertambangan Rakyat ataupun menetapkan suatu Wilayah Pertambangan Rakyat di Kota Samarinda

Konsultasi yang dilakukan oleh Walikota Samarinda dengan DPRD Kota Samarinda tidak akan pernah bisa dilaksanakan apabila pemerintah kota samarinda itu sendiri tidak pernah mengeluarkan Izin dan menetapkan suatu wilayah pertambangan rakyat di kota samarinda. Karena konsultasi tersebut hanya bisa dilaksanakan apabila pemerintah kota samarinda telah mengeluarkan izin pertambangan rakyat bagi penambang rakyat di kota samarinda.

3. Kewenangan Pemerintah Kota Samarinda dalam pengelolaan pertambangan Telah diambil alih oleh Pemerintah Provinsi Kalimantan Timur.

Kewenangan Pemerintah Kota Samarinda untuk melakukan penataan, pemanfaatan, pemulihan, pengawasan, dan pengendaliaan terhadap kegiatan pertambangan saat ini telah diambil alih oleh Pemerintah Provinsi Kalimantan Timur. Sehingga untuk melakukan penataan, pemanfaatan, pemulihan, pengawasan, dan pengendaliaan terhadap 
kegiatan pertambangan tersebut, pemerintah kota samarinda sudah tidak memiliki kewenangan lagi melainkan hal tersebut sudah menjadi kewenangan pemerintah provinsi Kalimantan Timur. Sehingga, Peraturan Daerah Nomor 12 Tahun 2013 Tentang Pertambangan Mineral dan Batubara dalam Wilayah Kota Samarinda tersebut dinilai tidak bisa lagi dijadikan sebagai landasan acuan untuk melakukan penataan, pemanfaatan, pemulihan,

\section{PENUTUP}

\section{A. Kesimpulan}

Mekanisme Penetapan Wilayah

Pertambangan Rakyat Oleh Walikota Samarinda yakni melakukan Penyusunan Rencana WPR, melakukan penyelidikan dan penelitian dalam rangka mempersiapkan WPR, melakukan koordinasikan dengan Pemerintah Provinsi DPRD kabupaten/kota, melakukan Penetapan Wilayah Pertambangan Rakyat (WPR) dengan memastikan lokasi WPR, luasan WPR, jenis komoditas yang ditambang, gambar peta lokasi WPR, Wilayah atau tempat kegiatan tambang rakyat yang sudah dikerjakan tetapi belum ditetapkan sebagai WPR diprioritaskan untuk ditetapkan sebagai WPR, WPR yang telah ditetapkan disampaikan secara tertulis oleh Walikota kepada Menteri dan Gubernur, Penetapan Wilayah Pertambangan Rakyat ditetapkan dengan Keputusan Walikota.

Bentuk Konsultasi Walikota Samarinda dengan Dewan Perwakilan Rakyat Daerah dalam Penetapan Wilayah Pertambangan Rakyat yakni dilakukan dalam bentuk tertulis. Isi materi di dalam konsultasi yakni Membahas Tentang Kriteria Penetapan Wilayah Pertambangan Rakyatnya, Membahas Hasil Penyusunan Rencana Wilayah Pertambangan Rakyat yang telah dilakukan oleh Walikota Samarinda, Membahas Hasil penyelidikan dan penelitian yang telah didapatkan oleh Walikota Samarinda yakni seperti Lokasi Wilayah Pertambangan Rakyat nya, Luasan Wilayah Pertambangan Rakyat nya, Jenis komoditas yang ditambang, Gambar peta lokasi Wilayah Pertambangan Rakyat nya. pengawasan, dan pengendaliaan terhadap kegiatan pertambangan di kota samarinda. Karena Pengaturan pertambangan di kota samarinda saat ini hanya berlandaskan UU Nomor 4 Tahun 2009 Tentang Pertambangan Mineral dan Batubara.

\section{B. Saran}

Seharusnya Mekanisme untuk menetapkan wilayah pertambangan rakyat oleh walikota samarinda itu di implementasikan secara baik sejak dikeluarkannya Peraturan Daerah Nomor 12 tahun 2013 tentang pertambangan mineral dan batu bara dalam wilayah kota samarinda.

Sebaiknya konsultasi yang dilakukan oleh walikota samarinda dengan DPRD Kota Samarinda itu tidak hanya di lakukan dalam bentuk tertulis. Akan tetapi, agar lebih efektif maka harus dilakukan secara lisan dengan cara rapat koordinasi. Dan Sebaikya Peraturan Daerah Nomor 12 Tahun 2013 Tentang Pertambangan Mineral dan Batu Bara dalam wilayah Kota Samarinda itu dibatalkan atau di cabut karena sudah tidak efektif lagi dalam Implementasinya. 


\section{DAFTAR PUSTAKA}

\section{A. Daftar Buku}

Adrian Sutedi, Hukum Pertambangan, Sinar Grafika, Jakarta, 2011

Amiruddin dan Zainal Asikin, Pengantar Metode Penelitian Hukum, RajaGrafindo Persada, jakarta, 2004

Bagir Manan dan W. Riawan Tjandra dan Kresno Budi Harsono, Legislatif Drafting Teori dan Teknik Pembuatan Peraturan Daerah, Universitas Atmajaya, Yogyakarta, 2009

Budiman NPD, Ilmu Pengantar PerundangUndangan, UII press, Yogyakarta, 2005

Diana Halim Koentjoro, Hukum Administrasi Negara, Ghalia Indonesia, Jakarta, 2004

Maria Farida S, Ilmu Perundang-undangan I, Kanisius (Anggota IKAPI), Yogyakarta, 2007

Muh. Nasir, Metode Penelitian, RajaGrafindo Persada, jakarta, 2010

Muchtar Kusumaatmadja, Aspek Hukum Dan Kelembagaan Dalam Peningkatan Efisiensi Dan Efektifitas Pengelolaan Wilayah Pesisir, Pustaka Yustisia, Yogyakarta, 2009

Nandang Sudarjat, Teori dan Praktik Pertambangan Indonesia Menurut Hukum, Pustaka Yustisia, Yogyakarta, 2010

Nasution, S. Metode Penelitian Naturalistikkualitatif, RajaGrafindo Persada, jakarta, 1996

Rosyidi Rangga Widjaja dikutip oleh Soimin, Pembentukan Peraturan Negara Di Indonesia, 2010

Salim HS, Hukum Pertambangan Di Indonesia, Raja Grafindo Persada, Jakarta, 2007

Salim HS, Hukum Pertambangan Mineral dan Batubara, Sinar Grafika, Jakarta, 2012

Soerjono Soekanto dan Sri Mamudji, Penelitian Hukum Normatif Suatu Tinjauan Singkat, RajaGrafindo Persada, jakarta, 2003

Wiratno, Pengantar Hukum Administrasi Negara, Universitas Trisakti, Jakarta, 2011

\section{B. Peraturan Perundang-undangan}

Undang-Undang Dasar 1945

Undang-Undang Nomor 4 Tahun 2009 Tentang Pertambangan Mineral dan Batu Bara.

Undang-Undang Nomor 23 Tahun 2014 tentang Pemerintahan Daerah Jo UndangUndang Nomor 9 Tahun 2015 tentang Perubahan kedua atas UndangUndang Nomor 23 Tahun 2014.

Peraturan Pemerintah Nomor 23 Tahun 2010 Tentang Pelaksanaan Kegiatan Usaha Pertambangan Mineral dan Batubara.

Peraturan Daerah Nomor 12 Tahun 2013 Tentang Pertambangan Mineral dan Batubara dalam Wilayah Kota Samarinda. 